\title{
Implementasi Manajemen Sumber Daya Manusia
}

\author{
Rahmah Utamy ${ }^{\bowtie 1}$, Syarwani Ahmad ${ }^{2}$, Syaiful Eddy ${ }^{3}$ \\ (1) Sekolah Menengah Kesujuan Negeri 1 Lais \\ $(2,3)$ Universitas PGRI Palembang
}

$\triangle$ Corresponding author

[utamy.rahmah@gmail.com]

\begin{abstract}
Abstrak
Penelitian ini bertujuan untuk mendeskripsikan dan menyajikan mengenai implementasi manajemen sumber daya manusia melalui indikator perencanaan, rekrutmen, seleksi, orientasi dan penempatan, pelatihan dan pengembangan, dan penilaian kinerja di SMK Negeri 1 Lais serta hambatan-hambatan dalam implementasi manajemen sumber daya manusia di SMK Negeri 1 Lais Kabupaten Musi Banyuasin. Adapun pendekatan yang digunakan dalam penelitian ini adalah pendekatan kualitatif. Berdasarkan hasil analisis data, maka diketahui bahwa implementasi manajemen sumber daya manusia di SMK Negeri 1 Lais telah terlaksana dengan baik, ditandai dengan adanya penyusunan perencanaan sumber daya manusia, perekrutan sumber daya manusia yang profesionalisme dan transparan, pelaksanaan seleksi sumber daya manusia yang cukup profesional, pelaksanaan orientasi dan penempatan kerja yang memperhatikan kebutuhan sekolah dan kompetensi guru/karyawan, pelaksanaan pelatihan dan pengembangan yang terencana, dan penilaian kinerja. Walaupun dari segi seleksi, orientasi dan penempatan belum terlaksana dengan baik. Faktor penghambat implementasi manajemen sumber daya manusia yaitu: kurangnya kesejahteraan guru dan pegawai honorer, kurangnya kejelasan karier, dan penjaminan mutu
\end{abstract}

Kata Kunci: Implementasi; Manajemen; Sumber Daya Manusia

\begin{abstract}
This study presented the implementation of human resource management through indicators of planning, recruitment, selection, orientation and placement, training and development, and performance costs at SMK Negeri 1 Lais as well as obstacles in the implementation of human resource management at SMK Negeri 1 Lais, Musi Banyuasin Regency. The approach used in this study is a qualitative approach. Based on the results of data analysis, it is known that the implementation of human resource management at SMK Negeri 1 Lais has been carried out well, calculations with the preparation of human resource planning, professional and transparent recruitment of human resources, implementation of fairly professional resource selection, implementation of orientation, and job placements that pay attention to teacher / employee training and competence, implementation of planned training and development. Although in terms of selection, orientation and placement have not been carried out well. Inhibiting factors for the implementation of resource management are: the welfare of teachers and honorary staff, lack of career clarity, and quality assurance.
\end{abstract}

\section{Keyword: Implementation; Management; Human Resource.}

\section{PENDAHULUAN}

Pendidikan merupakan sistem dan cara meningkatkan kualitas hidup manusia dalam segala aspek kehidupan. Dalam sejarah umat manusia, hampir tidak ada sekelompok manusia yang tidak menggunakan pendidikan sebagai alat pembudayaan dan peningkatan kualitasnya, sekalipun dalam masyarakat yang masih terbelakang/primitif (Sanaky, 2003). Pendidikan merupakan sarana yang paling efektif dan efisien untuk mentransformasikan ilmu pengetahuan, budaya dan lain sebagainya dari satu generasi ke generasi berikutnya. Pendidikan merupakan salah satu pranata yang terlibat langsung dengan masa depan umat manusia (Abudinata, 2003).

Keanekaragaman baik buruknya mutu pendidikan di Indonesia terjadi pada setiap jenis dan jenjang pendidikan, baik dilihat dari segi proses maupun hasil. Hal ini bisa dilihat dari hasil lulusan siswa maupun mahasiswa yang masih sulit bersaing dalam ajang kompetisi ilmiah, kesempatan kerja karena masih rendahnya kemampuan teknis serta moral lulusan lembaga pendidikan. Masalah utama yang sering dialami oleh banyak institusi adalah peran yang dimainkan oleh manajemen (Sallis, 2012). Hal tersebut dikarenakan penempatan tenaga tidak sesuai dengan bidang keahliannya dan penanganan masalah bukan oleh ahlinya (Mulyasa, 2011). 
Education is the most important indicator of a country's progress (Asvio et al, 2019; Kristiawan dan Muhaimin, 2019). Education is a conscious effort to build quality human resources to compete (Tobari et al, 2018). Quality of human resources are more important than the wealth of natural resources, because the wealth of natural resources cannot guarantee the welfare and success of a nation (Asvio et al, 2019; Kristiawan dkk, 2017). Human resources quality will increase a quality country (Rahmadoni, 2018).

Tolak ukur kualitas suatu bangsa ini, dapat dilihat dari sejauh mana keberhasilan pelaksanaan pendididikan itu berlangsung dalam sebuah negara. Semakin tinggi tingkat pendidikan masyarakat di suatu bangsa, maka semakin tinggi pula kualitas masyarakat bangsanya. Namun realitas sistem pendidikan Indonesia belumlah menunjukkan kualitas dan keberhasilan yang diharapkan. Pendidikan nasional belum bisa menciptakan SDM yang unggul, baik dari sisi intelektualitas, moralitas, spritualitas, profesionalitas dan kemampuan daya saing atau kompetisi bangsa. Dan dalam kenyataannya pendidikan di Indonesia sulit mengalami kemajuan yang berarti, bahkan dalam sekala global kualitas kita jauh dari negara-negara tetangga.

Berbicara mengenai implementasi atau pelaksanaan manajemen SDM dalam upaya peningkatkan mutu pendidikan adalah merupakan persoalan yang sangat penting untuk ditelusuri, karena berhasil atau tidaknya lembaga pendidikan banyak dipengaruhi faktormenajemen sumber daya manusia. Dalam konteks inidijelaskan bahwa sumber daya manusia pendidik dan tenaga kependidikan merupakan ujung tombak dari suatu lembaga pendidikan.

Manajemen SDM harus terlibat aktif dalam perencanaan, pengelolaan serta pengendalian organisasi yang berkaitan dengan alokasi dan pengembangan SDM. Merubah sistem kerja yang responsive menjadi proaktif, dan struktur fungsional ke struktur yang lebih fleksibel dan melaksanakan kebijakan strategis (Rachmawati, 2004). Sejalan dengan itu, bagi dunia pendidikan dukungan Manajemen SDM yang kuat dan komitmen kepala sekolah merupakan hal yang mutlak untuk keberhasilan organisasi secara menyeluruh serta pengembangan dan usaha meraih keunggulan kompetitif dan peningkatan mutu pendidikan.

Sebagai ilmu terapan dari ilmu manajemen, manajemen sumber daya manusia pendidikan memiliki fungsi manajemen dengan penerapan di bidang sumber daya manusia pendidikan. Fungsi manajemen sumber daya manusia pendidikan dapat dibagi dua, yaitu fungsi manajemen dan operasional. Fungsi-fungsi manajemen terdiri dari perencanaan, pengorganisasian, pengarahan dan pengendalian. Fungsi-fungsi operasional terdiri dari pengadaan, pengembangan, kompensasi, pengintegrasian, pemeliharaan, kedisiplinan, dan pemberhentian (Hasibuan, 2003).

Dengan fungsi manajemen sumberdaya manusia berupa penarikan, seleksi, pengembangan, pemeliharaan dan penggunaan sumber daya manusia diharapkan dapat untuk mencapai tujuan-tujuan individu maupun organisasi pendidikan.

Peran manajemen sumber daya manusia di sebuah organisasi sangat strategis. Peran yang dilakukan terkait dengan kebijakan rekrutmen, penempatan, penggajian/ pemberian kompensasi dan pengembangan karier yang didasarkan pada kompetensi. Tugas MSDM yang paling utama berkaitan dengan kegiatan administrasi seperti rekrutmen, sistem penghargaan, promosi, dan sebagainya. MSDM juga harus dapat mengusahakan penciptaan SDM yang berkualitas untuk mewujudkan tujuan organsasi. Dalam dunia kerja komitmen pegawai terbukti dapat memperkirakan perilaku pegawai yang secara teratur khususnya terkait dengan presensi pegawai tersebut (Hasan, 2019).

Sebagai agen of change perubahan sosial, sesungguhnya pendidikan dalam atmosfir modernisasi dan globalisasi dewasa ini dituntut untuk mampu memainkan perannya secara dinamis proaktif. Pendidikan diharapkan mampu membawa perubahan dan kontribusi yang berarti bagi perbaikan posisi manusia, baik pada dataran sumber daya manusia secara intelektual, moral, spiritual maupun pada dataran yang bersifat praktis dalam bentuk solusi-solusi bagi problematika manusia. Dan bagi sekolah yang dikelola dengan manajemen yang profesional akan tumbuh sehat dan kuat, sehingga dapat terus berimprovisasi, mengembangkan program-program yang credible dan marketable. Pada gilirannya menjadi program-program unggulan masyarakat. Sebaliknya, sekolah yang tidak dikelola dengan professional sehingga tidak mampu memenuhi tuntutan dan harapan stakeholder maka berangsur-angsur akan ditinggalkan masyarakat.

Sumber daya manusia seperti pendidik dan tenaga kependidikan merupakan unsur aktif, sedangkan unsur-unsur yang lain merupakan unsur pasif yang bisa diubah oleh kreativitas manusia. Oleh karena itu, dengan pengelolaan sumber daya manusia yang berkualitas diharapkan dapat mengoptimalkan potensipotensi yang dimiliki agar mampu mendukung terbentuknya pendidikan yang berkualitas. Dalam kenyataannya, lembaga pendidikan sering berhadapan dengan persoalan-persoalan manajerial dan administratif para manajer pendidikan pada berbagai jenis posisi dan tingkatan. Hambatan yang cukup besar dalam upaya meningkatkan kualitas pendidikan adalah masih sedikitnya tenaga profesional dalam bidang manajemen pendidikan (Sujanto, 2007; Zulaiha dkk, 2020) yang dimiliki oleh suatu lembaga. Jadi, fungsi pembinaan dan pengembangan pegawai merupakan fungsi pengelolaan personil yang mutlak perlu, untuk memperbaiki, menjaga, dan meningkatkan kinerja pegawai (Mulyasa, 2011).

Untuk mengatasi berbagai persoalan di atas, selain persoalan tentang peranan dan aktivitas manajemen, tampaknya lembaga pendidikan tidak cukup hanya dengan melakukan berbagai langkah dan 
aktivitas manajerial semata, tapi lebih dari itu aktivitas manajerial pun dituntut harus bisa mewujudkan tujuan yang berorientasi pada peningkatan mutu lembaga, seperti salah satunya adalah bagaimana manajemen sekolah berupaya untuk meningkatkan kepuasan kehidupan kerja personel (Rachmawati, 2004).

Dari keseluruhan gambaran tentang kondisi lembaga pendidikan di atas, menjadi realitas obyektif yang terjadi hampir diseluruh sekolah di Indonesia, baik sekolah negeri maupun swasta. Meskipun sekolah negeri sedikit lebih diuntungkan dengan kecukupan sarana dan fasilitas, namun secara umum mereka pun masih dihadapkan pada problem-problem yang cukup kompleks khususnya berkaitan dengan kemandirian lembaga untuk mengembangkan visi kelembagaan. Sehingga daya saing sekolah negeri pun belum cukup mampu berbicara banyak dalam konteks peningkatan mutu serta ketatnya persaingan dunia pendidikan. Begitu juga sekolah swasta yang tentu saja mempunyai berbagai macam persoalan, mulai dari dana, sumber daya manusia, sarana prasarana yang menuntut pihak sekolah untuk selalu berperan aktif dalam mengatasi berbagai persoalan tersebut. Tidak terkecuali di SMK Negeri, SMK sebagai mata rantai penyelenggara pendidikan tentunya dihadapkan dengan berbagai rintangan yang berat. Salah satu dari SMK Negeri tersebut adalah SMK Negeri 1 Lais.

Setiap organisasi akan membutuhkan MSDM termasuk pada bidang pendidikan. SMK Negeri 1 Lais sebagai organisasi pendidikan bersifat dinamis dan kompetitif, sehingga lembaga pendidikan dihadapkan dengan persaingan sesama lembaga tidak hanya kepemilikan sarana dan prasarana tetapi juga SDM (Winarti, 2018). Pendidikan dapat berjalan lancar dengan adanya manajemen sumber daya manusia yang dikelola dengan baik. Sekolah Menengah Kejuruan merupakan salah satu organisasi dibidang pendidikan yang sangat membutuhkan pengelolaan SDM dengan untuk dapat mewujudkan tujuannya.

Menurut Eaton (Soepetidjo, 2005) satu-satunya cara untuk memenangkan kompetisi ialah dengan sumber daya manusia. Dari pendapat tersebut dapat diketahui bahwa sumber daya manusia merupakan faktor terpenting di antara faktor- faktor lain.

SMK Negeri 1 Lais Kabupaten Musi Banyuasin beralamat di jalan Lais Bonot, SMK Negeri 1 Lais adalah SMK Negeri yang terletak di Provinsi Sumatera Selatan Kabupaten Musi Banyuasin dan berada di kecamatan Lais. Berdasarkan data dari Dinas Pendidikan Propinsi Sumatera Selatan Jumlah Seluruh SMK yang berada di Kabupaten Musi Banyuasin ada 23 SMK yang terdiri atas 16 SMK Negeri dan 7 SMK Swasta.

Berbagai permasalahanpun terjadi di institusi pendidikan ini, diantara permasalahan yang penulis temui antara lain : masih ada beberapa guru tidak sesuai antara kompetensi yang dimilikinya dengan mata pelajaran yang diajarkan, sumber daya manusia belum mencukupi, sarana prasarana pendidikan yang belum mencukupi, kurangnya kesejahteraan guru dan tenaga kependidikan, belum jelasnya pelaksanaan manajemen sumber daya manusia dan belum jelasnya proses perencanaan, perekrutan, dan prosedur seleksi sumber daya manusia di SMK Negeri 1 Lais.

Permasalahan yang terjadi di SMK Negeri 1 Lais juga banyak terjadi di Institusi pendidikan lainnya, seperti pada penelitian yang dilakukan oleh Ramby (2013) Mahasiswa Pasca Sarjana IAIN Sumatera Utara, dalam tesisnya yang berjudul Pelaksanaan Manajemen SDM dalam Meningkatkan Mutu Pendidikan di MTS Negeri 1 Padang Sidimpuan, disampaikan bahwa pada Madrasah ini terdapat permasalahan pada perencanaan, pengorganisasian, pelaksanaan serta pengawasan sumber daya manusia dalam meningkatkan mutu pendidikan.

Pada tesis yang ditulis oleh Rahmi (2017) mahasiswa Pasca Sarjana UIN Alaudin Makassar dengan judul Penerapan Manajemen SDM dalam peningkatan Kinerja Guru di SD Unggul Puri Taman Sari Kota Makassar ditemukan bahwa sumber daya manusia pada sekolah tersebut dapat dikategorikan baik dan memadai secara kuantitas maupun kualitas. Penerapan manajemen SDM oleh Kepala Sekolah dilaksanakan dengan baik terutata dalam hal penempatan SDM, pemberian honor sebagai insentif sesuai tugas beban kerja guru dan kegiatan guru.

Oleh karenanya, menurut penulis setelah mengamati kondisi sekolah serta penelitian-penelitian terdahulu yang relevan, untuk diteliti dan dikaji lebih mendalam, bagaimana implementasi manajemen sumber daya manusia di SMK Negeri 1 Lais Kabupaten Musi Banyuasin. Demikian, dapat menjadi feed back bagi program implementasi itu sendiri maupun sebagai bahan kajian dan pembanding di tempat lain dalam meningkatkan mutu dan kualitas dalam pendidikan.

\section{METODE PENELITIAN}

Penelitian ini termasuk Field Research, yaitu penelitian langsung terjun ke lokasi yang telah ditentukan (Soehardi, 2001). Adapun pendekatan yang digunakan dalam penelitian ini adalah pendekatan kualitatif. Sehingga dalam penelitian kualitatif ini, peneliti akan lebih mendapatkan informasi dan data yang dibutuhkan pada penelitian ini, diharapkan dengan kondisi tersebut akan lebih memaksimalkan hasil penelitian yang diperoleh.

Fokus penelitian dimaksudkan untuk membatasi studi kualitatif sekaligus membatasi penelitian guna memilih mana data yang relevan dan mana data yang tidak relevan (Moleong, 2010). Pembatasan dalam penelitian kualitaif ini lebih didasarkan pada tingkat kepentingan/ urgensi dari masalah yang dihadapi dalam 
penelitian ini. Penelitian berfokus kepada permasalahan implementasi manajemen sumber daya manusia di SMK Negeri 1 Lais Kabupaten Musi Banyuasin.

Prosedur pengumpulan dan perekaman data merupakan bagian terpenting dalam suatu penelitian. Karena tujuan utama penelitian adalah mendapatkan data. Tanpa mengetahui prosedur pengumpulan dan perekaman data, maka peneliti tidak akan mendapatkan data yang memenuhi standar data yang ditetapkan (Sugiyono, 2014).

Adapun teknik-teknik pengumpulan data tersebut adalah: 1) teknik pengamatan disebut observasi; 2) interview atau wawancara; 3) dokumentasi. Sejumlah besar fakta dan data tersimpan dalam bahan yang berbentuk dokumentasi. Sebagian besar data yang tersedia adalah berbentuk surat-surat, peraturan, kebijakan, absensi, laporan, foto dan sebagainya (Darmadi, 2013). Terdapat tahapan analisis data yang dilakukan dalam penelitian kualitatif, yaitu analisis domain, taksonomi, dan komponensial, analisis tema.

\section{HASIL DAN PEMBAHASAN}

\section{Implementasi Manajemen Sumber Daya Manusia di SMK Negeri 1 Lais Kabupaten Musi Banyuasin}

Memperhatikan dan menelaah hasil observasi dan wawancara mendalam terdahulu dengan para nara sumber yang dilengkapi dengan studi dokumentasi, maka telah dipaparkan deskripsi umum tentang temuan dan hasil penelitian yang berkaitan dengan implementasi manajemen sumber daya manusia di SMK Negeri 1 Lais, yang meliputi perencanaan, rekrutmen, seleksi, orientasi dan penempatan, pelatihan dan pengembangan, dan penilaian kinerja.

Dari hasil temuan tersebut, kemudian penulis berupaya untuk melakukan sebuah analisis hasil penelitian terkait dengan implementasi manajemen sumber daya manusia di SMK Negeri 1 Lais. Analisis ini dilakukan dengan melihat fakta-fakta dan temuan lapangan sebagaimana yang telah dideskripsikan terdahulu, dan membandingkannya dengan konsep atau pun teori yang ada dalam manajemen sumber daya manusia.

Untuk perencanaan sumber daya manusia, berdasarkan hasil kajian yang telah peneliti lakukan terhadap hasil wawancara dengan nara sumber, terdapat temuan-temuan penelitian sebagai berikut: 1) perencanaan SDM SMK 1 Negeri 1 Lais dilakukan melalui kegiatan analisa faktor penyebab perubahan tenaga kerja yang terjadi, melalui evaluasi tahunan yang dilakukan secara berkala dan dilaksanakan setahun sekali; 2) menyusun perencanaan untuk menentukan kebutuhan atas tenaga apa saja dan apa juga kriteria yang diperlukan oleh calon pelamar yang nantinya akan direkrut; 3) melakukan analisis sumber internal sebelum melakukan dan menentukan implementasi program penarikan tenaga; 4) implementasi program perencanaan SDM terkait dengan kebijakan untuk merekrut tenaga honorer yang dilakukan oleh pihak manajemen sekolah.

Dalam konteks manajemen sumber daya manusia bagi sekolah, perencanaan menurut Efendi (2005) merupakan "proses penentuan kebutuhan sumber daya manusia pada masa yang akan datang berdasarkan perubahan-perubahan yang terjadi dan persediaan tenaga yang ada di sekolah".

Hasil temuan penelitian yang dilakukan peneliti tentang perencanaan SDM yang dilakukan manajemen SMK Negeri 1 Lais seperti tersebut diatas secara garis besar sesuai dengan langka-langkah dalam proses perencanaan menurut Efendi (2005) dalam bukunya, Manajemen Sumber Daya Manusia sebagai berikut: Pertama, melakukan analisis beberapa faktor penyebab perubahan kebutuhan sumber daya manusia, kedua, peramalan kebutuhan sumberdaya manusia, ketiga, menentukan kebutuhan sumber daya manusia di masa yang akan datang keempat, Analisis ketersediaan sumber daya manusia, dan kelima, penentuan dan implementasi program.

Analisis faktor penyebab perubahan tenaga kerja yang dilakukan oleh manajemen SMK Negeri 1 Lais adalah mengetahui apakah jumlah tenaga telah mencukupi, kurang atau berlebihan, apakah terdapat tenaga yang akan pensiun, mutasi dan sebagainya. Sesuai apa yang disampaikan Efendi (2005), bahwa perubahanperubahan tenaga kerja organisasi sebagai sesuatu yang alami dan yang akan terjadi, seperti kebutuhan tenaga kerja baru sebagai akibat adanya pegawai yang pensiun, mengundurkan diri, pemutusan hubungan kerja, mutasi, meninggal dunia dan lain-lain.

Setelah menganalisa berbagai faktor yang mempengaruhi atau menyebabkan perubahan kebutuhan sumber daya manusia, selanjutnya manajemen SMK Negeri 1 Lais menyusun perencanaan untuk menentukan kebutuhan atas tenaga apa saja dan apa juga kriteria yang diperlukan oleh calon pelamar yang nantinya akan direkrut. Dan penentuan jenis dan kriteria tenaga yang dibutuhkan dilakukan secara bersama-sama dengan melibatkan para pengelola sekolah untuk memberikan masukan dalam menentukan kebutuhan tenaga tersebut.

Proses perencaaan sumber daya manusia yang dilaksanakan di SMK Negeri 1 juga sejalan dengan konsep perencanaan SDM menurut Haromain (2014), SDM merupakan aset organisasi yang tidak tergantikan sehingga kualitas SDM yang seperti apa dan berapa jumlah yang dibutuhkan suatu organisasi harus merekrut dan mempekerjakannya. Keberhasilan pencarian tenaga kerja merupakan awal kualitas kinerja bagi organisasi. Dasar analisis ini akan dibuat perencanaan sumber daya manusia dalam jangka pendek 1 tahun, jangka menengah 5 tahun dan jangka panjang di atas 5 tahun. Perubahan tersebut termasuk dalam 
perencanaan SDM terutama kebutuhan terhadap tenaga kerja proaktif. Analisis kebutuhan SDM tidak hanya secara kuantitas tetapi juga secara kualitas yang dibutuhkan organisasi (Haromain, 2014).

Untuk rekruitmen sumber daya manusia, setelah perencanaan SDM maka dilakukan tahapan rekrutmen dan seleksi. Rekrutmen adalah pencarian karyawan dipasar tenaga kerja (Wibowo, 2017). Organisasi dapat mencari tenaga kerja melalui berbagai cara seperti media massa, alumni, kantor tenaga kerja, dan sebagainya. Rekrutmen harus diperhatian dengan baik karena akan berdampak pada seleksi dan kinerja baik pegawai maupun nantinya kepada organisasi (Aziz dkk, 2017). SMK melakukan rekrutmen dan seleksi mengikuti ketentuan organisasi yang ada menaunginya. SMK berada di bawah pemerintah provinsi sehingga rekrutmen pegawai PNS mengikuti ketentuan CPNS pemerintah provinsi. Untuk pegawai honorer dilakukan melalui informasi dari mulut ke mulut atau dengan rekomendasi.

Berdasarkan paparan data temuan-temuan penelitian yang berkaitan dengan rekruitmen SDM di SMK Negeri 1 Lais adalah: 1) ada dua pola rekrutmen yang ada di SMK Negeri 1 Lais, yaitu pertama, rekrutmen tenaga tetap (ASN/PNS) yang dilaksanakan oleh oleh pemerintah. Kedua, rekrutmen tenaga guru/ karyawan tidak tetap atau honorer yang dilakukan sepenuhnya oleh manajemen sekolah; 2) menentukan tentang jabatan atau pekerjaan dan persyaratan yang dibutuhkan; 3) menentukan sumber dan metode rekrutmen; 4) dalam proses rekrutmen manajemen SMK Negeri 1 Lais berupaya untuk menerapkan prinsip profesionalisme dan transparansi.

Rekrutmen menjadi salah satu kegiatan yang sangat penting dalam manajemen sumber daya manusia sebab sebagai awal dari kegiatan yang dilakukan organisasi sekolah untuk mendapatkan pegawai yang tepat untuk mengisi jabatan yang kosong. Ada dua pola rekrutmen yang ada di SMK Negeri 1 Lais, yaitu pertama, rekrutmen tenaga tetap (ASN/PNS) yang dilaksanakan oleh Pemerintah dalam hal ini adalah Badan Kepegawaian Daerah bersama dengan Dinas Pendidikan Provinsi. Kedua, rekrutmen tenaga guru/ karyawan honorer yang dilakukan sepenuhnya oleh manajemen sekolah.

Dalam proses perekrutan manajemen sekolah menentukan terlebih dahulu tentang jabatan/pekerjaan yang kosong dan persyaratan yang dibutuhkan bagi tenaga yang akan dipekerjakan di sekolah. Persyaratan jabatan merupakan kriteria atau ciri-ciri yang dapat meliputi keahlian, pengetahuan, keterampilan dan pengalaman yang diperlukan untuk melakukan pekerjaan. Persyaratan jabatan ini tentu saja harus ditentukan sebab hal itu akan membantu mengidentifikasi pegawai yang dibutuhkan dan berkaitan dengan siapa yang dibutuhkan dan di mana mereka berada (Efendi, 2005).

Langkah terahir dalam proses rekrutmen yang dilaksanakan manajemen SMK Negeri 1 Lais adalah menentukan sumber dan metode rekrutmen. Untuk sumber dan metode ini manajemen sekolah membagi ke dalam beberapa sumber dan metode, yakni sumber internal meliputi calon tenaga baru yang dimungkinkan dapat diperoleh dari tenaga yang sudah ada dan bekerja di sekolah dengan menggunakan metode tertutup, artinya kepala sekolah akan memberikan tugas baru kepada tenaga tersebut berdasarkan kemampuan dan prestasi kerja yang telah dilakukannya. Atau dengan kata lain calon internal diperoleh dengan cara pimpinan memberikan atau menominasikan beberapa orang sebagai calon untuk dipromosi (Efendi, 2005).

Sedangkan untuk sumber eksternal yang terdiri atas orang-orang yang belum menjadi tenaga sekolah dan akan direkrut, dalam proses rekrutmen ini manajemen SMK Negeri 1 Lais berupaya untuk menerapkan prinsip profesionalisme dan transparansi, artinya manajemen sekolah memberikan kesempatan secara terbuka kepada para calon pelamar yang memiliki kemampuan atau kompeten dalam bidangnya untuk mengajukan lamaran pekerjaannya sesuai dengan pilihan yang dikehendaki dengan berdasarkan ketentuan dan juga syarat yang diberberlakukan oleh manajemen sekolah. Sesuai dengan pendapat Efendi (2005) bahwa penggunakan metode terbuka untuk sumber eksternal, melalui job posting, yaitu organisasi sekolah mengumumkan jabatan yang kosong pada papan pengumuman, pengumuman lisan, atau media lain sehingga memberikan kesempatan pada semua pegawai untuk mengajukan lamaran secara formal.

Dari analisis diatas dapat dilihat bahwa metode rekrutmen yang dilaksanakan oleh manajemen SMK Negeri 1 Lais terdapat kesamaan dengan pendapat Efendi (2005), tentang langkah-langkah yang harus diperhatikan dalam merekrut tenaga kerja untuk sekolah, yaitu: a) penentuan jabatan yang kosong; b) penentuan persyaratan jabatan; dan c) penentuan sumber dan metode rekrutmen.

Upaya rekrutmen mandiri yang dilakukan oleh manajemen sekolah terhadap kebutuhan tenaga guru dan pegawai ini menurut hemat penulis memiliki beberapa keuntungan, meskipun pada sisi yang lain hal ini juga berarti semakin besarnya beban sekolah terutama berkaitan dengan tanggung jawab untuk memberikan kesejahteraan kepada guru dan pegawai tersebut.

Sisi positif dari rekrutmen guru dan pegawai secara mandiri ini adalah, Pertama, manajemen sekolah dapat lebih cermat untuk menentukan para calon guru dan pegawai sesuai dengan spesifikasi dan kualifikasi yang dibutuhkan oleh sekolah. Kedua, dalam limit waktu yang sangat mendesak proses rekrutmen dapat dilakukan secara lebih cepat, sehingga kebutuhan guru dan pegawai yang mendesak dapat segera dipenuhi. Ketiga, para guru dan pegawai honorer biasanya lebih memiliki ikatan yang kuat dengan sekolah sebagai lembaga yang mengangkat mereka, hal ini berbeda dengan guru dan pegawai berstatus negeri yang terkadang 
mereka kurang memiliki ikatan dengan lembaga karena yang mengangkat dan menggaji mereka adalah pemerintah.

Keuntungan lain dari upaya rekrutmen mandiri ini adalah manajemen sekolah dapat menilai sendiri kapasitas calon guru dan pegawai melalui proses seleksi yang mereka lakukan, baik berkaitan dengan kemampuan professional calon guru dan pegawai maupun komitmennya terhadap tugas. Dalam proses ini manajemen sekolah dapat menetapkan standar-standar tersendiri sesuai dengan yang dibutuhkan oleh sekolah. Misalnya berkait dengan kualitas/prestasi akademik, pengalaman mengajar, asal perguruan tinggi, latar belakang keilmuan dan sebagainya. Dari proses ini memang dirasakan nilai positif terhadap penampilan guru dan pegawai dalam menjalankan tugasnya. Hal ini tentu sangat berbeda dengan guru dan pegawai yang di paket oleh pemerintah. Tidak jarang guru dan pegawai yang ditugaskan tidak sesuai dengan kebutuhan sekolah.

Untuk seleksi sumber daya manusia yang dilakukan oleh manajemen SMK Negeri 1 Lais sesungguhnya adalah untuk menyaring pelamar dengan setepat mungkin sesuai dengan harapan dan kebutuhan yang diinginkan. Seperti namanya, seleksi, maka fungsi tahap ini adalah menyaring pelamar dengan setepat mungkin sehingga organisasi dapat menerima orang yang tepat.

Seleksi dilakukan setelah didapatkan pelamar tenaga kerja. Seleksi adalah pemilihan sejumlah pelamar yang sesuai dengan perencanaan dan persyaratan kerja organisasi (Wibowo, 2017). Seleksi dapat dilakukan melalui berbagai tes ataupun tahapan dari seleksi adminsitrasi hingga tes tulisan atau lisan. Proses seleksi dimaksudkan untuk mengetahui pengetahuan dan ketrampilan pelamar, serta kesesuaian sikap dan kepribadiannya dengan ketentuan organisasi. Saat ini kompetensi SDM yang perlu dikuasai adalah penggunaan teknologi informasi dan internet (Mardiyah, 2019).

Temuan penelitian yang berkaitan dengan seleksi SDM di SMK Negeri 1 Lais berdasarkan paparan data adalah: 1) melakukan dua tahap seleksi, yaitu seleksi awal dan seleksi lanjutan; 2) menggunakan sistem gugur dalam proses seleksi; 3) mengutamakan guru yang berpengalaman dan juga mempertimbangkan hal lain seperti referensi dari guru senior atau pihak yang mengetahui tentang kondisi pelamar.

Dalam melaksanakan proses seleksi ini, SMK Negeri 1 Lais, sesungguhnya melakukan dua tahap besar seleksi, yaitu seleksi awal dan seleksi lanjutan. Pertama, seleksi awal atau seleksi pendahuluan, manajemen sekolah melakukan penerimaan pendahuluan berupa seleksi administratif atau pemilahan atas berkas lamaran yang masuk dan mengambil hanya beberapa persen dari berkas lamaran tersebut. Meskipun pelamar tidak harus mendatangi sekolah untuk melakukan wawancara awal, namun baik pelamar ataupun manajemen sekolah telah dapat dipastikan mereka mengerti dan mengetahui terkait dengan kelengkapan informasi apa saja yang dibutuhkannya. Proses seleksi administratif ini pun biasa dikenal dengan istilah matrik atau pembuatan daftar nama peserta seleksi. Matrik ini kemudian digunakan sebagai alat untuk membandingkan lamaran dengan kriteria dan dengan masing-masing pelamar, sehingga pelamar yang paling memenuhi kriteria dimasukkan ke daftar nama peserta seleksi. Kedua, seleksi wawancara, setelah pelamar dianggap memenuhi syarat administrasi, maka pelamar tersebut akan dipanggil untuk melakukan tes wawancara.

Sesuai dengan Efendi (2005) tentang jenis-jenis tes yang biasa digunakan dalam menentukan calon pegawai oleh organisasi sekolah adalah knowledge test, performance test, aptitude tes dan psychological test. Knowledge test yaitu tes untuk mengetahui pengetahuan seseorang, misalnya pengetahuan mengenai ilmu tertentu, tes ini umumnya tertulis, tetapi untuk pengetahuan tertentu mungkin dapat dengan praktek seperti pengetahuan mengenai bahasa tertentu. Performance test, yaitu tes untuk mengetahui skill dan kemampuan pegawai pada saat ini, tes ini dapat dilakukan dengan tes tertulis atau praktek, dalam hal ini manajemen SMK Negeri 1 Lais melakukan tes micro teaching untuk calon pelamar guru. Aptitude test, yaitu tes untuk mengetahui potensi seseorang, untuk ditempatkan dalam pekerjaan tertentu atau untuk dikembangkan yaitu dengan melalui tes wawancara.

Dalam melakukan kegiatan tes tersebut manajemen sekolah membentuk tim untuk menangani masing-masing materi ujian dan disesuaikan dengan bidang penguji yang menanganinya. Ujian biasanya dilakukan secara tim, artinya untuk setiap calon pelamar akan menghadapi beberapa penguji.

Kemudian, seleksi dilakukan dengan menggunakan sistem gugur, artinya calon pelamar yang tidak lolos seleksi sebelumnya maka dinyatakan tidak dapat mengikuti seleksi selanjutnya. Dalam seleksi pun manajemen sekolah berupaya untuk memberikan gambaran atau penjelasan mengenai realitas dan tuntutan pekerjaan yang harus dilakukan oleh personel bilamana diterima di SMK Negeri 1 Lais.

Sebagaimana dijelaskan Efendi (2005) bahwa penjelasan pekerjaan secara realistis realistic job preview merupakan usaha memberikan gambaran atau penjelasan mengenai realitas pekerjaan. Hal ini diperlukan sebab ketika seorang pelamar memasuki organisasi sekolah, pelamar tersebut akan memperoleh kesan tentang berbagai hal yang bisa positif atau negatif mengenai organisasi sekolah, misalnya akan mendapatkan gaji yang sangat besar, pekerjaan yang menyenangkan, jam kerja yang ringan, beban kerja yang tidak berat dan lain-lain. 
Di samping itu, dalam kegiatan seleksi ini juga manajemen SMK Negeri 1 Lais sangat memperhatikan dan mempertimbangkan faktor pengalaman akan tetapi kita juga mempertimbangkan hal lain seperti referensi dari guru senior atau pihak yang mengetahui tentang kondisi pelamar. Menurut penulis adanya referensi dari guru senior ini menjadikan seleksi SDM menjadi tidak obyektif lagi karena biasanya referensi dari guru senior ini lebih mengedepankan unsur subyektivitas sehingga berpengaruh terhadap proses seleksi. Sehingga tanpa adanya seleksi yang memadai, seseorang pelamar bisa diterima menjadi guru/karyawan SMK Negeri 1 Lais.

Orientasi dan penempatan, organisasi yang telah mendapatkan pelamar yang sesuai dengan kualifikasi akan melakukan penempatan karyawan. Penempatan karyawan adalah menempatkan karyawan pada satuan tugas sesuai dengan keahlian (Wibowo, 2017).

Selain keahlian yang dimiliki oleh pegawai, perlu juga memperhatikan perencanaan SDM yang telah dilakukan pada proses sebelumnya. Penempatan karyawan akan berpengaruh terhadap kepuasan kerja karyawan (Karmita dkk, 2015).

Ketepatan penempatan karyawan akan mempengaruhi kinerja organsiasi. Selain itu, penempatan pegawai juga akan berpengaruh terhadap kinerja karyawan (Runtuwene dkk, 2016). Penempatan karyawan di SMK sesuai dengan kualifikasi terutama latar belakang pendidikan. Lulusan sarjana pendidikan akan ditempatkan sebagai guru sesuai kompetensinya. Akan tetapi untuk tenaga administrasi yang belum mempunyai kualifikasi khusus terkait program studi kelulusan kesarjanaannya. Tenaga administrasi lebih hanya mempertimbangkan kemampuan untuk melaksanakan pekerjaan.

Adanya personel baru yang direkrut dan diseleksi serta terdapatnya tantangan baru dalam lingkungan kerja mengakibatkan manjemen SMK Negeri 1 Lais harus melakukan pengaturan/ penempatan bagi personel baru atau pun personel lama untuk posisi yang baru. Sebelum melakukan penempatan, manjemen SMK Negeri 1 Lais mensosialisasikan personelnya pada pekerjaan baru melalui kegiatan orientasi untuk meningkatkan dukungan yang lebih efektif.

Berdasarkan temuan penelitian dalam orientasi dan penempatan pegawai di SMK Negeri $1 \mathrm{Lais}$ adalah sebagai berikut: 1) orientasi terhadap guru dan pegawai baru di SMK Negeri 1 Lais diberikan secara nonformal dan guru serta pegawai baru diharapkan untuk proaktif untuk melaksanakan adaptasi terhadap lingkungan sekolah; 2) untuk tahap penempatan, ada dua cara yang dilakukan manajemen sekolah. Pertama, dengan melakukan penempatan atau pengisian jabatan/pekerjaan bagi guru dan pegawai baru. Kedua, dengan memberikan penugasan kembali kepada guru atau pegawai lama atas tugas atau jabatan baru yang berbeda; 3) untuk penempatan guru dan pegawai dengan mempertimbangkan kompetensi dan kinerja.

Dari temuan penelitian di atas terlihat bahwa kegiatan orientasi di SMK Negeri 1 Lais masih ditempatkan sebagai kegiatan yang tidak begitu penting. Meskipun ada upaya-upaya untuk memperkenalkan dengan lingkungan, budaya dan rekan kerja, namun hal itu belum menjadi kebutuhan manajerial yang penting, sehingga tidak perlu dilakukan secara formal. Guru atau pegawai yang baru langsung diminta bekerja dan dibiarkan berusaha sendiri, dengan anggapan perlahan-lahan akan mengetahui sendiri mengenai tugastugasnya dan kondisi lainnya di lingkungan sekolah.

Temuan penelitian diatas berbeda dengan pendapat Nawawi (2005), bahwa program orientasi sesungguhnya merupakan suatu cara yang penting karena pada dasarnya merupakan usaha dalam membantu pegawai baru untuk mengenali dan memahami tugas-tugas mereka, kondisi organisasi, kebijakan organisasi, rekan sekerja, nilai-nilai, keyakinan-keyakinan dan lain-lain.

Di samping itu, seperti dikatakan oleh Alshoubaki dan Harris (2018) early interaction with the organization have lasting effect, maksudnya, interaksi pertama dengan sekolah akan mempunyai efek yang lama pada guru dan pegawai, sehingga pertemuan pertama dalam kegiatan orientasi harus dilakukan dengan baik, memberi kesempatan belajar tentang keseluruhan bidang, kegiatan sekolah, bimbingan pada guru dan pegawai baru yang akan meningkatkan kepuasan dan produktivitas kerja mereka.

Kegiatan selanjutnya kegiatan yang dilakuakan manajemen SMK Negeri 1 Lais adalah penempatan guru dan pegawai. Berdasarkan temuan penelitian, ada dua cara yang dilakukan manajemen sekolah dalam hal penempatan. Pertama, dengan melakukan penempatan atau pengisian jabatan/pekerjaan bagi guru dan pegawai baru. Kedua, dengan memberikan penugasan kembali kepada guru atau pegawai lama atas tugas atau jabatan baru yang berbeda.

Ini sesuai dengan pendapat Efendi (2005) bahwa penempatan merupakan proses penugasan/pengisian jabatan atau penugasan kembali pegawai pada tugas/jabatan baru atau jabatan yang berbeda. Penugasan ini dapat berupa penugasan pertama untuk pegawai sekolah yang baru direkrut, tetapi dapat juga melalui promosi, pengalihan dan penurunan jabatan atau bahkan pemutusan hubungan kerja bagi pegawai sekolah yang telah bekerja.

Penempatan ini dilakukan dengan memperhatikan personel, artinya untuk personel yang memang sama sekali baru maka manajemen sekolah biasanya langsung memberikan tugas sesuai dengan tanggung jawab yang dibebankan kepadanya dan menempati posisi yang memang telah tersedia formasinya. Begitu pun untuk personel yang sebelumnya memang sudah bertugas dan kemudian mendapatkan tugas baru atau 
ditempatkan untuk pekerjaan lain lagi, maka diharapkan mereka juga mampu untuk menyesuaikan diri dengan pekerjaan dan jabatan barunya itu. Untuk penempatan guru dan pegawai manajemen sekolah betul-betul mempertimbangkan kompetensi dan kinerjanya dan melakukan secara hati-hati dan penuh dengan perhitungan, artinya personel yang akan mendapatkan posisi baru itu merupakan personel yang memang benar-benar memiliki kompetensi dan prestasi kinerja yang baik.

Guru dan pegawai yang memiliki kompetensi dan kinerja yang baik akan mendapatkan promosi jabatan artinya menaikkan jabatan seorang pegawai sekolah ke jabatan lain yang memiliki tanggung jawab lebih besar. Sebaliknya guru atau pegawai yang kompetensi serta kinerjanya kurang baik akan mendapatkan demosi, yaitu pemindahan pegawai sekolah dari jabatan lain yang memiliki tanggung jawab yang lebih rendah, gaji lebih rendah dan level sekolah yang lebih rendah (Efendi, 2005).

Dari analisis temuan diatas dapat disimpulkan bahwa orientasi guru dan pegawai baru yang dilasanakan manajemen SMK Negeri 1 Lais belum dilaksanakan secara secara baik, sedangakan untuk penempatan guru dan pegawai dilukukan dengan dua cara, yaitu untuk guru dan pegawai baru langsung ditugaskan sesuai dengan formasinya masing-masing, sedang untuk pegawai yang sudah bertugas langsung diberikan tugas baru tentunya dengan mempertimbangakan kompetensi dan kinerjanya.

Pelatihan dan pengembangan guru dan pegawai ini dilakukan oleh SMK Negeri 1 Lais berdasarkan program-program yang telah disusun oleh manajemen sekolah sebagai bentuk komitmen dan keseriusannya dalam meningkatkan dan mengembangkan mutu pendidikan yang unggul, terampil dan berkepribadian mandiri. Semua itu menjadi kebutuhan organisasi yang diwujudkan melalui pendekatan dari strategi sekolah dengan memperhatikan lingkungan saat ini dan masa yang akan datang.

Selanjutnya berdasarkan paparan data dari hasil wawancara, observasi dan didukung dengan studi dokumentasi, ditemukan temuan penelitian sebagai berikut: 1) pelatihan di SMK Negeri 1 Lais telah melakukan pelatihan yang berupa arahan-arahan, bimbingan atau motivasi yang terprogam melalui pertemuan mingguan dan bulanan; 2) pendidikan dan pelatihan Guru dan Pegawai, SMK Negeri 1 Lais dilaksanakan melalui In House Training baik dilaksanakan sendiri maupun bekerjasama dengan sekolah lain, juga melalui Musyawarah Guru Mata Pelajaran, melalui beberapa pendidikan dan pelatihan yang berupa seminar, penataran maupun diklat yang diselenggarakan oleh pemerintah, selain itu juga program studi lanjut, melalui beasiswa dari pemerintah maupun biaya mandiri; 3) kegiatan diselenggarakan oleh pihak pemerintah lebih sering diperuntukkan bagi guru dan pegawai dengan status negeri. Sedangkan guru dan pegawai swasta masih sangat minim.

Berdasarkan hasil kajian, penulis membagi pola atau metode pelatihan dan pengembangan yang dilakukan oleh manajemen SMK Negeri 1 Lais dalam bentuk on the job training seperti yang dilakukan oleh Efendi (2005) yaitu dilakukan pada waktu jam kerja berlangsung, baik secara formal maupun informal, dan off the job training, yaitu pelatihan dan pengembangan yang dilakukan secara khusus di luar pekerjaan.

Dengan demikian dapat dijeaskan bahwa: Pertama, pola in the job site dan metode on the job training, nampaknya lebih dipilih oleh manajemen sekolah dalam mengembangkan kemampuan guru dan pegawai, yakni dengan memberikan arahan-arahan, bimbingan, motivasi baik verbal maupun non verbal, yang semuanya terlembagakan dalam bentuk program kegiatan yang riil melalui pertemuan migguan setiap hari senin setelah upacara bendera selama 40 menit dan pertemuan bulanan dilaksanakan setiap tanggal satu, pada saat jam kerja. Kedua, pola off the job site dan metode off the job training, yakni dengan menyusun atau lebih tepatnya berpartisipasi dalam program pelatihan dan pengembangan guru dan pegawai dan dilakukan secara khusus di luar jam pekerjaan. Dalam hal ini ada beberapa jenis program pelatihan dan pengembangan yang diikuti oleh guru dan pegawai seperti penataran, MGMP dan studi lanjut. Seperti yang dijelaskan dalam data dokumentasi bahwa terdapat 5 orang guru yang telah lulus S2 dan 4 orang dalam proses penyelesaian S2 di berbagai perguruan tinggi di Palembang.

Dari rangkaian kegiatan pelatihan dan pengembangan yang diikuti dan dilakukan oleh manajemen SMK Negeri 1 Lais, ternyata telah memberikan dampak positif bagi sekolah, terutama dalam sisi perubahan perilaku personel dan juga perbaikan organisasi. Meskipun hal ini tidak selamanya bisa menjamin karena memang masih ada saja personel-personel yang sulit untuk diarahkan dan dibimbing.

Penilaian kinerja, sebagai lembaga yang memperhatikan pentingnya kinerja, penilaian kinerja yang dilakukan manajemen SMK Negeri 1 Lais adalah hal penting yang harus dilakukan, dan harus lebih diperhatikan dalam pengelolaan kinerjanya. Pengelolaan atau manajemen kinerja adalah cara untuk memberikan pendekatan yang lebih terintegrasi dan berkelanjutan daripada yang diberikan oleh pendekatan yang terisolasi dan terkadang menggunakan skema penilaian kinerja yang tidak memadai.

Dari temuan penelitian dapat diketahui bahwa penilaian kepala sekolah terhadap kinerja para guru meliputi: 1) penilaian pelaksanaan proses KBM berupa supervisi kelas; 2) penilaian pelaksanaan pekerjaan secara periodik selama satu tahun yang diwujudkan dalam bentuk format tertentu yang dikenal dengan istilah SKP bagi Pegawai Negeri Sipil (ASN/PNS); 3) penilaian model raport yang berupa catatan-catatan kepala sekolah. 
Kemudian, berdasarkan temuan penelitian tentang penilain kinerja tersebut, penulis membagi metode penilaian kinerja yang dilakukan oleh manajemen SMK Negeri 1 Lais meliputi dua hal: Pertama, penilaian kinerja dari aspek kuantitatif, yakni penilaian yang dilakukan dengan menggunakan skor seperti penilaian yang terdapat pada SKP yang dilakukan sekali dalam satu tahun. SKP tersebut dilaporkan kepada pemerintah, dalam hal ini adalah Dinas Pendidikan. SKP inilah sebagai raportnya seorang guru (ASN/PNS) dalam melaksanakan pekerjaannya. Penilaian aspek kuantitaif ini merupakan penilaian yang berorientasi masa lalu, artinya penilaian perilaku kerja pada masa lalu sebelum penilaian dilakukan (Efendi, 2005).

Kedua, penilaian dari aspek kualitatif, yakni penilaian yang dilakukan tidak berdasarkan skor hanya berisi uraian atau catatan penilai terhadap kinerja personel, seperti penilaian model raport yang berupa catatan-catatan kepala sekolah dan supervisi yang dilakukan dalam proses kegiatan belajar mengajar. Hasil supervisi menjadi catatan kepala sekolah sebagai dasar untuk melakukan penilaian dan melihat kekurangan serta kelebihan seorang guru dalam melaksanakan KBM. Selanjutnya Kepala Sekolah akan memberikan masukan terhadap hasil supervisinya kepada guru yang bersangkutan agar dapat meningkatkan kualitas kegiatan pembelajarannya. Penilaian aspek kualitatif ini merupakan penilaian yang berorientasi masa yang akan datang, artinya penilaian yang dilakukan untuk mengidentifikasi aspek-aspek perilaku kerja yang perlu diperbaiki pada masa yang akan datang (Efendi, 2005).

Selanjutnya, hasil penilaian ini menjadi masukan yang baik bagi manajemen sekolah untuk memberikan evaluasi berupa pemberian umpan balik terhadap personel terkait dengan kinerja yang telah dilakukannya. Evaluasi itu meliputi tentang bagaimana manajemen sekolah memberikan dan menentukan insentif yang layak diterima oleh personel, memberikan pertimbangan dalam pelibatan personel dalam pelaksanaan tugas lain serta menjadi dasar pertimbangan untuk proses pembinaan dan pengembangan selanjutnya.

\section{Hambatan dalam Implementasi Manajemen Sumber Daya Manusia di SMK Negeri 1 Lais Kabupaten Musi Banyuasin}

Adapun faktor-faktor penting yang dapat menghambat implementasi manajemen sumber daya manusia di SMK Negeri 1 Lais adalah:

Kesejahteraan, yakni masih minimnya tingkat penghasilan pokok atau kompensasi dalam bentuk langsung yang diterima oleh sebagian pegawai dan guru SMK Negeri 1 Lais, terutama mereka yang masih berstatus swasta atau honorer. Kondisi ini dikhawatirkan cenderung akan mendorong timbulnya beberapa perilaku yang tidak menguntungkan dalam upaya untuk mengembangkan dan meningkatkan mutu lembaga yang sehat/baik.

Sehingga apabila suatu organisasi tidak mampu mengembangakan dan menerapaka suatu sistem manajemen kompensasi yang memuaskan, organisasi bukan hanya akan kehilangan tenaga-tenaga trampil dan berkemampuan tinggi, tetapi juga akan kalah bersaing dengan organisasi lain. Dan apabila hal tersebut terus berlanjut organisasi yang bersangkutan akan tidak mampu menghasilakan produk yang sesuai dengan tujuan dan sasaran yang ingin dicapainnya.

Karir, masalah kejelasan karier belum menjadi agenda manajemen sekolah untuk merencanakan dan melaksanakan bantuan agar para personel terutama guru dan pegawai swasta atau honorer yang potensial dapat dipersiapkan untuk mengantisipasi tantangan masa depan dalam melaksanakan tugas pokok organsisasi dan sekaligus dapat membantu personel tersebut untuk memenuhi salah satu kebutuhan pokoknya. Sehingga apabila suatu organisasi tidak mampu mengembangkan dan menerapkan suatu sistem manajemen karir yang memuaskan, organisasi bukan hanya akan kehilangan tenaga-tenaga trampil dan berkemampuan tinggi, tetapi juga akan kalah bersaing dengan organisasi lain. Dan apabila hal tersebut terus berlanjut organisasi yang bersangkutan akan tidak mampu menghasilkan produk yang sesuai dengan tujuan dan sasaran yang ingin dicapainnya.

Komunikasi mutu yakni masalah penyampaian pesan-pesan mutu yang dilakukan oleh manajemen SMK Negeri 1 Lais masih belum cukup efektif. Hal ini dapat diketahui melalui beberapa indikasi tentang masih adanya sebagian guru atau pegawai yang memiliki motivasi lemah dan kurangnya kesadaran rasa memiliki dengan memperlihatkan bagaimana pekerjaan mereka kurang sejalan dengan keseluruhan tujuan organisasi sekolah.

\section{SIMPULAN}

Implementasi manajemen sumber daya manusia di SMK Negeri 1 Lais telah terlaksana dengan baik, ditandai dengan adanya penyusunan perencanaan sumber daya manusia, perekrutan sumber daya manusia yang profesionalisme dan transparan, pelaksanaan seleksi sumber daya manusia yang cukup profesional, pelaksanaan orientasi dan penempatan kerja yang memperhatikan kebutuhan sekolah dan kompetensi guru/karyawan, pelaksanaan pelatihan dan pengembangan yang terencana, penilaian kinerja yang. Walaupun dari segi seleksi, orientasi dan penempatan belum terlaksana dengan baik. Faktor penghambat implementasi manajemen sumber daya manusia di SMK Negeri 1 Lais yaitu kurang dan belum maksimal akan sektor 
kesejahteraan, kejelasan karir bagi guru dan karyawan yang potensial perlu menjadi perhatian dan penjaminan mutu yang masih perlu mendapat perhatian khususnya untuk guru dan pegawai yang masih berstatus swasta. Sementara itu faktor pendukung implementasi manajemen sumber daya manusia di SMK Negeri 1 Lais yaitu kepemimpinan yang profesional dan lingkungan kerja yang kondusif.

\section{UCAPAN TERIMA KASIH}

Terima kasih yang sebesar-besarnya kami ucapkan kepada Kepala Sekolah SMK Negeri 1 Lais Kabupaten Musi Banyuasin, Rektor Universitas PGRI Palembang, Direktur Program Pascasarjana Universitas PGRI Palembang dan Program Studi Manajemen Pendidikan Universitas PGRI Palembang yang telah memberikan dukungan kepada kami untuk melakukan hal yang luar biasa ini. Proyek ini didanai secara independen. Kami juga ingin berterima kasih kepada teman-teman kami di Manajemen Pendidikan yang banyak membantu kami dalam menyelesaikan proyek ini dalam jangka waktu yang terbatas.

\section{DAFTAR PUSTAKA}

Abudinata. (2003). Manajemen Pendidikan. Jakarta: Prenada Media.

Alshoubaki, W., \& Harris, M. (2018). The Impact of Syrian Refugees on Jordan: A Framework Analysis. Journal of International Studies, 11 (2).

Asvio, N., Yamin, M., \& Risnita. (2019). Influence of Leadership Style, Emotional Intelligence and Job Satisfaction toward Organizational Commitment (Survey at SMA Muhammadiyah South Sumatera). International Journal of Scientific \& Technology Research 8 (8).

Aziz, T. A., Maarif, M. S., \& Sukmawati, A. (2017). Pengaruh Rekrutmen dan Seleksi Terhadap Kinerja. Jurnal Aplikasi Bisnis Dan Manajemen. https://doi.org/10.17358/jabm.

Darmadi, H. (2013). Dimensi-Dimensi Metode Penelitian Pendidikan dan Sosial. Bandung: Alfabeta.

Efendi, M. T. (2005). Manajemen Sumber Daya Manusia. Jakarta: Grasindo.

Haromain, H. (2014). Manajemen Pengembangan Sumber Daya Manusia (SDM) Pondok Pesantren. Jurnal Pendidikan Humaniora (JPH). https://doi.org/10.17977/JPH.V1/2.4047

Hasan, G. (2019). Motivasi, Kepuasan, Karakteristik, Kepemimpinan dan Keadilan Terhadap Komitmen Organisasi. Efisiensi - kajian ilmu administrasi. https://doi.org/10.21831/efisiensi.v16i1.24474

Hasibuan, M. S. P. (2003). Manajemen Sumber Daya Manusia. Jakarta: Bumi Aksara.

Karmita, S. B., Supartha, I. W. G., \& Priantini, P. S. (2015). Pengaruh Motivasi Kerja Dan Penempatan Kerja terhadap Kepuasaan Kerja dan Kinerja Karyawan (Studi pada Analis Kredit PT.BPD Bali Cabang Utama Denpasar). E-Journal Ekonomi Dan Bisnis Universitas Udayana. https://doi.org/10.1038/273554a0

Kristiawan, M., Safitri, D., \& Lestari, R. (2017). Manajemen Pendidikan. Yogyakarta: Deepublish.

Kristiawan, M., \& Muhaimin. (2019). Teachers' Obstacles in Utilizing Information and Communication Technology. International Journal of Educational Review, 1 (2).

Mardiyah, S. U. K., Kumoro, J., Kusuma, C. S. D., \& Rusdiyanto, W. (2019). Analisis Kompetensi Mahasiswa Program Studi Sekretari dalam Praktik Kerja Lapangan. Efisiensi - Kajian IImu Administrasi. https://doi.org/10.21831/efisiensi.v15i2.2448

Moleong, L. J. (2010). Metodologi Penelitian Kualitatif. Bandung: Remaja Rosdakarya.

Mulyasa. (2011). Manajemen Berbasis Sekolah, Konsep, strategi dan Implementasi. Bandung: PT Remaja Rosdakarya.

Nawawi, H. (2005). Manajemen Strategik Organisasi NonProfit Bidang Pemerintahan. Yogyakarta: Gajah Mada University Press.

Rahmadoni, J. (2018). Global Issues of Education Financing Management in SD Indonesian Creative School Pekanbaru. Jurnal Manajemen, Kepemimpinan, dan Supervisi Pendidikan 3(2), Juli-Desember 2018.

Rachmawati, E. N. (2004). Paradigma Baru Manajemen Sumber Daya Manusia sebagai Basis Meraih Keunggulan Kompetitif. Yogyakarta: Ekonisia.

Rahmi. (2017). Penerapan Manajemen SDM dalam Peningkatan Kinerja Guru di SD Unggul Puri Taman Sari Kota Makasar. Tesis, UIN Alaudin, Makasar. (belum diterbitkan).

Ramby. (2013). Pelaksanaan Manajemen SDM dalam Meningkatkan Mutu Pendidikan di MTS Negeri 1 Padang Sidimpuan, Tesis, IAIN Sumatera Utara, Medan. (belum diterbitkan).

Runtuwene, P., Tewal, B., \& Mintardjo, C. (2016). Pengaruh Penempatan Kerja, Mutasi dan Beban Kerja terhadap Kinerja Karyawan Pada PT. Bank Sulutgo Manado. Jurnal Berkala IImiah Efisiensi. 
Sallis, E. (2012). Total Quality Management in Education Manajemen Mutu Pendidikan. Jogyakarta: IRCiSoD. Sanaky, H. (2003). Paradigma Pendidikan Islam: Membangun Masyarakat Madani Indonesia. Yogyakarta: Safiria Insani Press.

Soehardi, S. (2001). Pengantar Metodologi Penelitian. Yogyakarta: Pena Persada Press.

Soepetidjo, B. (2005). Membangun Komitmen SDM. http://www.hri.or.id/urunrembug 001.htm

Sugiyono. (2014). Metode Penelitian Pendidikan; Pendekatan Kuantitatif, Kualitatif dan R\&D. Bandung: Alfabeta.

Sujanto, A. (2007). Psikologi Perkembangan. Jakarta: Rineka Cipta.

Tobari., Kristiawan, M. \& Asvio, N. (2018). The Strategy of Headmaster on Upgrading Educational Quality in Asean Economic Community (AEC) Era. International Journal of Scientific \& Technology Research 7 (4).

Wibowo. (2017). Manajemen Sumber Daya Manusia (Edisi Revisi). Bandung: Alfabeta.

Winarti, E. (2018). Perencanaan Manajemen Sumber Daya Manusia. Jurnal Tarbiyatuna, Volume 3 Nomor 1 hal. 1-26.

Zulaiha, D., Lian, B., \& Mulyadi. (2020). The Effect of Principal's Competence and Community Participation on The Quality of Educational Services. Journal of Social Work and Science Education, 1 (1) 